\title{
Study on Bacillus Isolated from Intestine of Persian Sturgeon (Acipenser persicus) Comparing with Commercial Probiotics
}

\author{
Mahsa Tabari ${ }^{1, a^{*}}$, Khashayar Tabari ${ }^{2}$, Hassan Karimzadegan ${ }^{3}$ \\ and Mehrdad Mohammadi ${ }^{4}$ \\ ${ }^{1}$ Department of Food Science and Technology, Tehran North Branch, Islamic Azad University, \\ Tehran, Iran. \\ ${ }^{2}$ Young Researchers Club, Lahijan Branch, Islamic Azad University, Lahijan, Iran. \\ ${ }^{3}$ Department of Environmental Management, Faculty of Environment and Energy, \\ Science and Research Branch, Islamic Azad University, Tehran, Iran. \\ ${ }^{4}$ Department of Food Technology Research, National Nutrition and Food Technology Research \\ Institute, Faculty of Nutrition Sciences and Food Technology, Shahid Beheshti University \\ of Medical Sciences, Tehran, Iran. \\ $\mathrm{a}^{*}$ ma.tabari@gmail.com
}

Keywords: Persian sturgeon larvae, Probiotic bacteria, Comparison test, Special Growth Rate.

\begin{abstract}
At present, probiotic bacteria are proposed as an important alternative for antibiotic elimination and for providing renewable products through biological control in cultivation systems of marine fish larvae. The aim of this study is to compare the effects of native and commercial probiotics on growth parameters of Persian sturgeon (Acipenser persicus) larvae fed with controlled biomar diet. Experimental diets with three probiotic bacterial mixture including commercial lactobacillus (L. plantarum and L. rhamnosus), commercial Bacillus (B. subtillis and B. licheniformis) and Bacillus isolated from intestine of Persian sturgeon (B. mycoides) were completed in two levels (6.1 and 7.2 log CFU in each g of feed) and were fed to larvae of Persian sturgeon in six experimental treatments. The control treatment was fed with diet without supplementation. The experiment was done in randomized design. In all the treatments, feed conversion index was increased considerably and had significant difference with control treatment and in all the experimental treatments influenced by probiotics were higher than that of control treatment $(\mathrm{P}<0.05)$. The highest rate means of special growth $(1.84 \pm 0.21 \%)$ and thermal growth index $(3.44 \pm 0.37 \%)$ was obtained respectively in treatment $\mathrm{C} 1$ and $\mathrm{C} 2$ (isolated from intestine). Maximum special growth rate (SGR \%) were obtained from C1 $(4.69 \pm 0.71 \%)$ and B2 $(4.62 \pm 0.87 \%$, commercial Bacillus). In addition, native probiotic bacteria had better performance than the non native commercial species as well as selection of suitable probiotic (natural) with respect to fish species, region and condition of culture plays a special importance role in enhancing the yield of Persian sturgeon larvae.
\end{abstract}

\section{Introduction}

Success or failure in aquaculture programs depends on cultural condition of fish larvae, that is, infection due to bacteria in cultural condition may cause increased death and reduced production [1]. At the other hand, in order to prevent or reduce such undesirable events in fish larvae culture, special additives with their foods may be used which can be useful for health and food efficiency increasing, among these; antibiotics are such pharmaceutical additives which have been used in fish foods since 1950 [2]. The massive use of antimicrobials for disease control increases the selective pressure exerted on the microbial world according to the World Health Organization much needs to be done to reduce the overuse and inappropriate use of [3].

With respect to providing medicinal resistance in host which is considered as limitation of antibiotics, the importance of probiotic bacteria has been completely obvious, so that these bacteria or produced compounds by them, with desirable effects for host, have been used in aquaculture for 
diseases control and also as supplements for improving fish larval growth and in some cases have been applied as an antimicrobial compound for fish larvae. Many researchers have already investigated probiotic bacteria in aquaculture [4-6].

Some of verified performances related to these bacteria including competitive repulsion for other bacteria as well as probiotic preservatives for preventing from pathogenetic bacteria accumulation in digestive tract of host by secretion of compounds preventing other bacteria growth or competition for food and space and immune system stimulation of host in order to tolerate to environmental stimulus, can be mentioned [7,8]. Several studies show that probiotic bacillus with ability to produce antibiotic, amino acids, extracellular enzymes and positive dietary effects and their nonpathogenecity for aquatic animals, have been widely used in aquaculture industry [7-9].

Yanbo and Zirong in 2006 proposed that probiotic bacteria lead to reduced costs for fish culture and they obtained good results from applying probiotic commercial bacillus strains for increased growth and larvae survival of trout through supplementation with experimental diets were obtained [10]. Ziaei-Nejad et al in 2006 showed that probiotic Bacillus had considerable effect on growth and survival of white Indian shrimp larvae (Fennero penaeus indicus). In Microbial management, native species isolated from aquatic digestive tract, have played important roles in aquaculture purposes. Similar research were done by Ghosh et al in 2002 with Bacillus circulans isolated from intestine of fish species, Labeo rohita, in diets supplemented with them [12, 13]. Also, bacteria Lactobacillus fructivorans isolated from fish species, Sparus auratus, as well as Lactobacillus plantarum (L. plantarum) isolated from human feces, led to increased growth and survival of this fish, after supplementation with Artemia franciscana nauplii [14].

The aim of this study is to investigate the effect of three probiotic bacteria mixtures including commercial Bacillus and commercial Lactobacillus and Bacillus isolated from intestine of sturgeon fishes during supplementation with experimental diets on growth of Persian sturgeon larvae. This research can be useful in applying native and commercial bacteria for growth of Persian sturgeon larvae in our country.

\section{Material and Method}

\section{Mixtures of bacteria:}

Three different bacterial mixtures were considered for this experiment.

- The first mixture including two species of probiotic bacillus named, Bacillus subtillis and Bacillus licheniformis, were prepared in from of powder product from the cell Biotech company (PTCC).

- The second mixture included microbial powder product in which two species of lactobacillus probiotic including lactobacillus plantarum (L. plantarum) and lactobacillus rhamnosus (L. rhamnosus) were prepared by the cell Biotech Company.

- Third bacterial mixture consisted of bacteria isolated from intestine of sturgeon fish larvae. 20 pieces of Persian sturgeon larvae (Acipenser persicus) were selected and after 20 hours starvation, were anesthetized in carnation flower extract with concentration of $100 \mathrm{~m}$ in 1 . in order to eliminate bacteria on larvae's body surface, fish samples were placed in $0.1 \%$ chloride Benzoalkonium chloride solution for $60 \mathrm{~s}$ and then were completely rinsed with sterile distilled water. The intestine of the fish larvae in a very sterile condition were taken out and give it a longitudinal cut (using surgery blade) in order to extract its content and their intestine after isolation are put in a sterile plate and the physiological serum (nine time of weight) is added to it and homogenize in sterile porcelain mortar (it resulting suspension will be solution 0.1). After preparing homogen using saline sterile normal solution $(0.87 \% \mathrm{NaCl} \mathrm{W} / \mathrm{V})$, sequence dilutions were prepared in range of $10^{-2}$ to $10^{-8}$. From above dilutions, a volume equal to 100 micro liters were taken and were transported to pellets containing culture medium of Bacillus cereus agar and triptic soy agar (TCA) and were distributed in it. The above pellets were incubated in incubator for 24 hours in temperature of $30^{\circ} \mathrm{C}$ and forming colonies again were purely cultured in culture (TCA) medium [5, $12,13]$. 
Finally in laboratory, with regard to some phenotypic characteristics such as bacteria morph, colonies and also according to coloration reaction to gram as well as some biochemical standard tests such as catalase reaction, oxidase, glucose fermentation, arabinose, citrate autolysis, indole reaction, releasing sulfide hydrogen gas $\left(\mathrm{H}_{2} \mathrm{~S}\right)$, methyl color transformation, V-P test and resistance to different salinity percents $(0.2$ and $3 \%$ ), the genus Corynebacterium and Bacillus mycoides (B. mycoides) were isolated and then were purely incubated in culture triptic broth medium [15].

\section{Supplementation of rations:}

Experimental rations in three groups (commercial Lactobacillus, commercial Bacillus and Bacillus isolated from intestine of sturgeon fish) and each one in two levels were supplemented with probiotic mixtures. These bacterial suspensions, instead of each gram of biomar diet (manufactured in France) were added and homogenized. At last, two experimental rations were prepared with $1.6 \times 10^{6}\left(6.1 \log\right.$ colony unit) and $1.5 \times 10^{7}$ (7.2 log colony unit) Bacterial in each gram, ration, respectively. Bacterial rates' increasing was determined by each ration equal to one single logarithmic unit. Similarly, also in Lactobacillus group, the experimental rations were prepared with these bacterial concentrations from their powder products and were mixed with other rations and their homogenation suspension was prepared $[12,13,16]$.

For bacteria isolated from intestine of sturgeon fish, $10 \mathrm{ml}$ of bacteria isolated from intestine were removed and were centrifuged in centrifuge for 10 minutes with $5000 \mathrm{rpm}$ and then the resulting extract were prepared using spectrophotometer (Schimat $20 \mathrm{UV}-160$ model) at $610 \mathrm{~nm}$ wavelength, $6.1 \mathrm{log}$ colony unit of photo concentrations and $7.2 \mathrm{log}$ colony unit of each $\mathrm{ml}$ of bacterial suspension, after pure incubation in culture (TCB) medium. These two bacteria concentrations' isolated from sturgeon fish were added to rations based on respected method and were supplemented. After unifying rations, they were dried with $40^{\circ} \mathrm{C}$ temperature for 5 hours $(10 \%$ moisture) and with regard to fish larval requirements were sieved $(0.1 \mathrm{~mm}$ tiny sieve) and were given to them. In control treatment, fish larvae of Persian sturgeon fed ration with no probiotic bacteria $[12,13]$.

\section{Experiment design (plan):}

Experimental treatments were considered in three groups and each one in two levels. For each treatment, three replicates were considered. Feeding rate for fish larvae was determined according to dietary standard (water temperature - fish weight) amounted $10 \%$ of body weight and in 6 portion of a meal. Dietary residue was gathered from ponds with micropipette and was omitted from total provided food and consumed food was calculated daily.

\section{Growth index}

Growth index biology of fish was determined every five days and based on eight percent of living mass of fish larvae, the daily ration rate was investigated. At the end of experiment period, weight and the body length of fish larvae in each pond were determined after anesthesia in carnation extract (concentration of $100 \mathrm{mg}$ in 1 ) with digital balance at $0.01 \mathrm{~g}$ accuracy and caliper ranged 0.1 $\mathrm{mm}$ and some of growth index were determined.

\section{Special growth rate (SGR)}

$\mathrm{RSG} \%=\left[\mathrm{LnWt}_{2}-\mathrm{LnWT}_{1} / \mathrm{T}_{2}-\mathrm{T}_{1}\right] \times 100,[17]$

$\mathrm{LnWt}_{2}=\mathrm{Log}$ of natural final weight of fish $(\mathrm{g})$,

$\mathrm{LnWt}_{1}=\mathrm{Log}$ of natural weight of fish,

$t_{2}-t_{1}=$ Experiment period length (day).

\section{Food conversion rate (FCR)}

$\mathrm{FCR} \%=\mathrm{g}$ dry feed eaten/g live weight gain (V), [18]

The food eaten $(\mathrm{G})=\mathrm{g}$ dry feed eaten,

The resulted weight $=\mathrm{g}$ live weight gain. 


\section{Food conversion efficiency (FCE)}

$\mathrm{FCE} \%=$ [g live weight gain $/ \mathrm{g}$ dry feed eaten $) \times 100(\mathrm{~V})$,

The resulted weight $(G)=g$ live weight gain,

The dried feed $(G)=g$ feed eaten.

\section{Thermal growth coefficient (TGC)}

$\mathrm{TGC} \%=\left[\mathrm{Bw}_{2}{ }^{0.333}-\mathrm{Bw}_{1}{ }^{0.333} / \sum_{(\text {day-degrees })}^{o c}\right] \times 100$,

Second live mass weight of fish $(\mathrm{g})=\mathrm{Bw}_{2}$,

First live weight of fish $(\mathrm{g})=\mathrm{Bw}_{1}$,

Total of daily temperatures degree mean $=\Sigma_{(\text {day }- \text { degrees })}^{o c}$.

\section{Water quality standards:}

During experiment period, dissolved oxygen at the level of $7.5 \pm 0.65 \mathrm{mg}$ in 1 was maintained using electrical air system (Haila model). The dissolved oxygen and water $\mathrm{pH}$ were measured daily, respectively by oxygen detector system and water checker system, model HANA. Phosphate $\left(\mathrm{PO}_{4}\right)$, sulfate $\left(\mathrm{SO}_{4}\right)$, Nitrite $\left(\mathrm{NO}_{2}\right)$ and nitrate $\left(\mathrm{NO}_{3}\right)$ amounts were determined weekly with using spectrometer model hack. Also water thermal degree measuring was done every day in morning and evening.

\section{Statistical analysis:}

The analysis of obtained Data related to growth index and test for resistance to stress was done by one-way variance analysis, incompletely randomized design with using spss-16 software and by Duncan test in 0.05 levels.

\section{Results}

The results for probiotic effect on growth parameters of Persian sturgeon larvae are given in (Table 1). For final weight of fish larvae, better results were observed in treatments $C_{1}, B_{1}$, compared to control and other experimental treatments were in higher level and showed significant difference $(\mathrm{P}<0.05)$. The minimum averaged weight was in control treatment $(1.41 \pm 0.21 \mathrm{~g})$ and the maximum averaged weight of fish larvae $(1.84 \pm 0.21 \mathrm{~g})$ was in treatment $\mathrm{C}_{1}$ (Larvae fed by diet supplemented with Bacillus isolated from intestine of sturgeon fish with concentration about $6.1 \log$ colony unit in each gram).

Table 1: Growth index of trout larvae fed experimental diets supplemented with three probiotic mixtures.

\begin{tabular}{|l|l|l|l|l|l|}
\hline \multicolumn{1}{|c|}{ Treatment } & \multicolumn{1}{|c|}{$\begin{array}{c}\text { Overall } \\
\text { Weight(g) }\end{array}$} & $\begin{array}{c}\text { Food } \\
\text { Conversion } \\
\text { Rate (FCR) }\end{array}$ & $\begin{array}{c}\text { Food } \\
\text { Conversion } \\
\text { Efficiency } \\
(\text { FCE) }\end{array}$ & $\begin{array}{c}\text { Thermal } \\
\text { Growth } \\
\text { coefficient } \\
(\text { TGC) }\end{array}$ & $\begin{array}{c}\text { Special } \\
\text { Growth } \\
\text { Rate } \\
(\text { SGR \%) }\end{array}$ \\
\hline $\begin{array}{l}\text { Control (without } \\
\text { probiotic) }\end{array}$ & $1.41 \pm 0.21^{\mathrm{c}}$ & $1.08 \pm 0.29^{\mathrm{ab}}$ & $103.11 \pm 22.61^{\mathrm{c}}$ & $3.15 \pm 0.38^{\mathrm{c}}$ & $4.14 \pm 0.82^{\mathrm{b}}$ \\
\hline $\mathrm{L}_{1}(6.1 \mathrm{Log}$ CFU/g) & $1.68 \pm 0.21^{\mathrm{a}}$ & $0.97 \pm 0.21^{\mathrm{abc}}$ & $112.57 \pm 33.45^{\mathrm{a}}$ & $3.24 \pm 0.44^{\mathrm{bc}}$ & $4.42 \pm 0.77^{\mathrm{ab}}$ \\
\hline $\mathrm{L}_{2}(7.2 \mathrm{Log}$ CFU/g) & $1.71 \pm 0.21^{\mathrm{ab}}$ & $0.91 \pm 0.34^{\mathrm{abc}}$ & $113.58 \pm 23.57^{\mathrm{ab}}$ & $3.30 \pm 0.32^{\mathrm{bc}}$ & $4.55 \pm 0.62^{\mathrm{a}}$ \\
\hline $\mathrm{B}_{1}(6.1 \mathrm{Log}$ CFU/g) & $1.57 \pm 0.21^{\mathrm{a}}$ & $0.99 \pm 0.37^{\mathrm{ab}}$ & $110.48 \pm 31.59^{\mathrm{bc}}$ & $3.33 \pm 0.51^{\mathrm{bc}}$ & $4.48 \pm 0.98^{\mathrm{ab}}$ \\
\hline $\mathrm{B}_{2}(7.2 \mathrm{Log}$ CFU/g) & $1.69 \pm 0.21^{\mathrm{bc}}$ & $1.01 \pm 0.32^{\mathrm{abc}}$ & $115.31 \pm 27.23^{\mathrm{b}}$ & $3.25 \pm 0.45^{\mathrm{c}}$ & $4.62 \pm 0.87^{\mathrm{a}}$ \\
\hline $\mathrm{C}_{1}(6.1 \mathrm{Log}$ CFU/g) & $1.84 \pm 0.21^{\mathrm{a}}$ & $0.95 \pm 0.33^{\mathrm{b}}$ & $117.80 \pm 22.61^{\mathrm{bc}}$ & $3.41 \pm 0.42^{\mathrm{ab}}$ & $4.71 \pm 0.68^{\mathrm{a}}$ \\
\hline $\mathrm{C}_{2}(7.2 \mathrm{Log}$ CFU/g) & $1.71 \pm 0.21^{\mathrm{ab}}$ & $0.98 \pm 0.28^{\mathrm{abc}}$ & $110.85 \pm 22.61^{\mathrm{ab}}$ & $3.44 \pm 0.37^{\mathrm{bc}}$ & $4.69 \pm 0.71^{\mathrm{ab}}$ \\
\hline
\end{tabular}

a, b and c: Different Latin letters in each column is evidence for significances $(p<0.05)$ 
Food conversion rate (FCR) was reduced in experimental treatments and in treatments $\mathrm{C}_{1}$ $(0.95 \pm 0.33)$ and $\mathrm{L}_{2}(0.91 \pm 0.34)$ and the better results were obtained with control treatment and treatments $\mathrm{B}_{1}$ and $\mathrm{B}_{2}$ and had significant difference $(\mathrm{P}<0.05)$. Their highest rate was observed in control and $B_{2}$ treatments. The treatments $L_{1}, L_{2}, B_{1}, B_{2}$ and $C_{2}$ had no significant difference with each other $(\mathrm{p}>0.05)$. Also, food conversion efficiency (FCE percent) was in maximum level in treatment $\mathrm{C}_{1}(117.80 \pm 22.61 \%)$ and didn't show significant difference from control treatment and $\mathrm{A}_{1}, \mathrm{~A}_{2}, \mathrm{~B}_{1}, \mathrm{~B}_{2}, \mathrm{~L}_{2}$ treatments ( $>0.05$ ). The minimum level of this parameter was obtained in percent control treatment $(103.11 \pm 22.61)$. Thermal growth coefficient $(\mathrm{TGC} \%)$ of some experimental treatments showed standard rising and showed significant difference from control treatment $(\mathrm{p}>0.05)$. Also, its maximum mean in treatment $\mathrm{C}_{2}$ and its minimum mean in control and $\mathrm{L}_{1}$ treatments were obtained (respectively, $3.44 \pm 0.37 \%, 3.15 \pm 0.38$ ). Related to this parameter, there was no significant difference between treatments $B_{1}, B_{2}, L_{1}, L_{2}, C_{1}$ and $C_{2}(p>0.05)$. Special growth rate $(\mathrm{SGR} \%)$ of probiotic lactobacillus was obtained in 6.1 level of log Bacteria in gram (treatment $\left.\mathrm{L}_{2}\right)$ and had significant difference with control treatment $(\mathrm{p}>0.05)$.

The maximum yield of special growth rate in larvae fed by supplemented diets with bacillus isolated from intestine of sturgeon fish at 6.1 and 7.2 levels of log colony unit in Gram was related to treatments $\mathrm{C}_{1}$ and $\mathrm{C}_{2}$ and also it could be better option for improving larve producing.

\section{Discussion}

The effect of commercial probiotic bacteria about improving growth standards and increased survival of cultured fish is proved in many researches. Among probiotics used in this experiment, bacillus isolated from intestine of sturgeon fish had better growth performance (yield). Food conversion rate (FCR), being one of the most important nutritional indicators, was considerably reduced with applying probiotic bacteria and its better results were observed in treatments $\mathrm{C}_{1}$ $(0.95 \pm 0.33)$ and $\mathrm{L}_{2}(0.91 \pm 0.34)$. In this course, Jafaryan et al in 2009 showed that applying commercial probiotic bacillus mixtures in experimental diets of Persian sturgeon larvae, reduced FCR from 1.74 to 1.59 [19]. Also, in accordance with this research, Yanbo and Zirong in 2006 obtained similar results in supplementing diet of common carp (cyprinuscarpio) with probiotic bacillus sp, so that FCR was reduced significantly from 2.46 to 2.11 [10]. Bagheri et al obtained minimum FCR (0.9) in trout larvae fed by diets supplemented with bacillus subtilis at $3.8 \times 10^{9}$ bacteria in each gram feed level [20].

At present research, final weight of fish larvae in experimental treatments was increased compared to control treatment and showed significant difference. The best result was derived through supplementation rations with bacillus isolated from intestine of sturgeon fish in concentration of $6.1 \mathrm{log}$ colony unit in each gram feed. Similar to these results, Ghosh et al in 2004 confirmed that bacillus cerculance isolated from intestine of fish species, Labeo rohita, at the level equal to $2 \times 10^{8} \mathrm{CFU}$ feed, Changed the weight of fry from 3.45 to $4.61 \mathrm{~g}$ [21]. According to these results, Ghosh et al in 2002 showed that bacillus isolated from intestine of labeo rohita fish has more effect on increased weight of larvae of this fish than commercial bacillus $[12,13]$.

Bacillus isolated from intestine of sturgeon fish, compared to commercial bacillus had better performance for increasing the special growth rate and the best level of special growth rate was obtained in treatment $\mathrm{C}_{1}$. Also, commercial lactobacillus supplemented at level $7.2 \log$ colony unit in each gram, had better performance. Similar results were obtained by Ghosh et al in 2004 about supplementation of diets fed to Rohita fish larvae at level equal to $10^{8} \mathrm{CFU} / \mathrm{g}$ feed, so that special growth rate was increased from 10.89 to 17.79 [21]. Corresponding to these results, Jafaryan et al in 2009 showed that special growth rate of Persian sturgeon larvae fed by rations supplements with spore bacillus formis and bacillus laterosporus at concentration of $4 \times 10^{7}$ in each gram feed, was increased from 5.84 to 6.41 , of body weight. About this, Ghosh et al in 2002 proposed that bacillus isolated from intestine of cultured fish has better performance than commercial bacillus [12, 13]. 
In this research, probiotics increased thermal growth index in some experimental treatments. The best result was derived by bacillus isolated from intestine of sturgeon and in concentration supplementation about $6.1 \mathrm{log}$ colony unit in each $\mathrm{g}$ diet, while bacillus and commercial lactobacillus significantly. In this course, Balcazar et al in 2007, Mahmoud et al (2015) and Rengasamy et al in 2016 suggested that the different performance of probiotic bacteria can depends on parameters such as genetics, feeding and environmental factors [4, 22, 23]. Also, Bairagi et al in 2002 emphasized that lipolithic, amilolithic and proteolitic activities of probiotic bacteria increase food absorption and digestion in host intestine and as a results, growth and nutrition parameters are improved [24].

The results of this research illustrated that different levels of probiotics have different abilities to influence on growth yield and based on different given concentrations, this effect is variant and among these, probiotic bacillus isolated from intestine of sturgeon fish as native probiotic bacteria had better performance than commercial or nonnative species.

\section{References}

[1] D. Kapetanovic, B. Kurtovic, E. Teskeredzic, Difference in bacterial population in rainbow. trout (Onchorhynchus mykiss, Walbaum) fry after transfer from incubator to pools, Food technology and biotechnology. 43(2) (2005) 189-193.

[2] B. Ahilan, G. Shine, R. Santhanam, Influence of probiotics on the growth and gut microflora load of juvenile Gold fish (Carassius auratus), Asian Fisheries Science. 17 (2004) 271-278.

[3] World Health Organization (WHO) antimicrobial resistance fact sheet 194. Available: http://www.who.int/inf-fs/en/fact194.html

[4] M.A.O. Dawood et al., Interaction effects of dietary supplementation of heat-killed Lactobacillus plantarum and $\beta$-glucan on growth performance, digestibility and immune response of juvenile red sea bream, Pagrus major, Fish and Shellfish Immunology. 45(1) (2015) 33-42.

[5] D. Datta, S. Nath Talapatra, S. Swarnakar, Bioactive Compounds from Marine Invertebrates for Potential Medicines - An Overview, International Letters of Natural Sciences. 34 (2015) 42-61.

[6] P.D. Rabo et al., The Role of Fisheries Resources in National Development: A Review, International Letters of Natural Sciences. 18 (2014) 20-28.

[7] A. Irianto, B. Austin, Probiotic in aquaculture, J. Fish. Dis. 25 (2002) 1-10.

[8] S. Nikoskelainen et al., Immune enhancement in rainbow trout (Onchorhynchus mykiss) by potential probiotic bacteria (Lactobacillus rhamnosus), Fish Shelfish. Immunol. 15 (2003) 443-452.

[9] M. Gullian, F. Thompson, J. Rodriguez, Selection of probiotic bacteria and study of their immunostimulatory effect in Penneaus vannamei, Aquaculture. 233(1) (2004) 1-14.

[10] W. Yanbo, X. Zirong, Effect of probiotic for commom carp (Cyprinus carpio) based on growth performance and digestive enzymes activities, Anim. Feed. Sci. Technol. 127 (2006) 283-292.

[11] S. Ziaei-Nejad et al., The effect of Bacillus spp. Bacteria used as probiotics on digestive enzyme activity, survival and growth in the Indian white shrimp Fenneropenaeus indicus, Aquaculture. 252(2) (2006) 516-524.

[12] K. Ghosh, S.K. Sen, A.K. Ray, Characterization of Bacillus Isolated from the gut of Rohu, Labeo rohita, fingerlings and its significance in digestion, Journal of Applied Aquaculture. 12(3) (2002) 33-42. 
[13] K. Ghosh, S.K. Sen, A.K. Ray, Growth and survival of rohu, Labeo rohita [Hamilton] spawn fed diets supplemented with fish intestinal microflora, Acta Ichthyologica et piscatoria. 32(1) (2002).

[14] O. Carnevali et al., Administration of probiotic strain to improve sea bream wellenss during development, Aquaculture International. 12(4) (2004) 377-386.

[15] H. Peter, A. Sneath, Bergeys manual of systematic Bacteriology. Volume 2, Williams and Wilkins Co, Baltimore, 1986, pp. 78-120. ISBN 10: 0683078933.

[16] B. Gomez-Gil et al., Bioencapsulation of two different vibrio species in nauplii of the Brine shrimp (Artemia fransiscana), Applied and Environmental Microbiology. 64(6) (1998) 2318322.

[17] E. M. Hevroy et al., Nutrition utilization in Atlantic salmon (Salmo salar L) fed increased level of fish protein hydrolysate during a period of fast growth, Aquaculture Nutrition. 11(4) (2005) 301-313.

[18] S.S. De Silva, T.A. Anderson, The effect of ration on growth ratio, ln: Fish Nutrition in Aquaculture, Chapman, London, UK, 1995, pp. 319-380.

[19] H. Jafaryan et al., The use of probiotic bacillus bioencapsulated with Artemia urmiana nauplii for the growth and survival in Acipenser persicus larva, Journal of Agricultural Sciences and Natural Resources. 14(2) (2007) 87-97.

[20] T. Bagheri et al., Growth, survival and gut microbial load of rainbow trout fry given diet supplemented with probiotic during the two month of first feeding, Turkish J. Fish. Aqua. Sci. 8 (2008) 43-48.

[21] K. Ghosh, S.K. Sen, A.K. Ray, Growth and survival of rohu, Labeo rohita [Hamilton, 1822] spawn fed diets fermented with intestinal bacterium, Bacillus circulans, Acta Ichthyologica et piscatoria. 34(2) (2004) 155-165.

[22] J. L. Balcazar et al., Changes in itestinal microbiota and immune response following probiotic administration in brown trout (Salmo trutta), Br. J. Nutr. 97 (2007) 522-527.

[23] N. Rengasamy et al., A Study on the Therapeutic Ability of Gut Microbiota upon V. parahaemolyticus Infected Farm Prawn, International Journal of Pharmacology, Phytochemistry and Ethnomedicine. 2 (2016) 20-29.

[24] A. Bairagi et al., Enzyme producing bacterial flora isolated from fish digestive tracts, Aquaculture International. 10(2) (2002) 109-121. 